\title{
Interpretive Scholarship in Contemporary International Relations
}

\begin{abstract}
Interpretive International Relations (IR) has become a robust and diverse research programme, consolidating across various subfields of the discipline. However, this is a recent phenomenon. While early classical realists and English School scholars clearly drew on interpretive thought, these contributions did not coalesce into a welldefined and specifically interpretive research agenda. The 'interpretive turn' in social sciences and humanities in the 1970s and epistemological pluralisation of political science and IR in the 1990s slowly made space for interpretive theory and research. This paper reconstructs, first, what makes interpretive IR distinct, and, second, what it means to engage in interpretive inquiry in this field, conceptually and substantively. It discusses in particular the implications of the monist ontological position that interpretivists tend to occupy and the conditions of knowledge production within the hermeneutical circle. These reject the possibility of transcending the context and bring to bear the researcher's involvement in knowledge production as inevitable but generative. The paper also explicates the still poorly understood concept of 'intersubjectivity' as being defining for the interpretivist sensibility and one which directly contests positivist ideals. Interpretive IR scholarship serves as a veritable showcase for interpretive research practice, and points to the growing significance and volume of such scholarship.
\end{abstract}

Keywords: interpretivism, International Relations, intersubjectivity, contextualism, reflexive methodology

\section{Introduction}

What does it mean to conduct interpretive inquiry in International Relations (IR) and to engage in interpretive policy analysis in international politics? While an interpretive sensibility marks the thought of classical realists (Wolfers, 1952) and English School scholars (Bevir, Hall, 2020), it was explicitly introduced to the discipline in the 1990s (Neufeld, 1993; Lynch, 1999) and initially presented 
as mainly a counter-paradigm to the epistemological and normative grip of the positivist mainstream. This introduction was sparked at least partially and perhaps belatedly by the 'interpretive turn' in the social sciences against behaviouralism (Geertz, 1973; Taylor, 1971; Rabinow, Sullivan, 1987; Burawoy, 1998). The recent return to interpretivism in IR unfolds within a broader agenda of streamlining interpretive approaches in political science (Bevir, 2000; Bevir, Phillips, 2019; Bliesemann de Guevara, 2016; Bevir, Rhodes, 2016; Rhodes, 2017; Heinelt, Münch, 2018; Wagenaar 2011; Yanow, Schwartz-Shea, 2006; Schwartz-Shea, Yanow, 2012; Wedeen, 2010). Just like elsewhere, the interpretive opening in IR signifies a distinct ethos of 'emancipation' from the dominance of the orthodoxy. Such aims are still valid. But interpretive scholarship in IR has also moved from defensive and marginal positions to a robust and thriving agenda that offers more contextual, reflexive, granular, and practice-oriented perspectives on contemporary phenomena in international politics.

In studies on European foreign policy, for example, interpretive approaches bring both a critical reshuffling and an insight into the sociology of the field. They no longer only serve for advancing the project of the EU but also look into the contested meanings of the project itself, within the EU and in its interaction with other actors (Kurowska 2018, p. 273). This is one of many indicators that the hard-won legitimacy of interpretive approaches is no longer discarded outof-hand. Lynch's breakthrough re-reading of the discipline through an interpretive lens (Lynch, 2014) both systematised interpretive inquiry in the field and revealed the interpretive interface of much of the post-Second World War IR. And yet misunderstandings and a certain aura of estrangement persist (Kurowska, Bliesemann de Guevara, 2020). In response, the aim of this paper is to contribute to a better understanding and a popularisation of the interpretive sensibility and research practice. I first discuss interpretivism as a study of meaningmaking practices of contextually embedded human actors and consider what defines interpretive scholarship in IR, despite its internal variety and diversity. Philosophical monism provides for the ontological foundation of interpretivism and its ensuing intersubjective grounding in the social reality, while abduction as the logic of inquiry reflects the premises of the hermeneutical circle (Gadamer, 1989). The latter involves a particular understanding of reflexivity as a constant probing of the researcher's positionality, which constitutes part and parcel of knowledge production. Second, I bring in scholarship by several IR interpretivists who have impacted flagship IR literatures and put forward frameworks for analysis which systematise interpretive IR theory and research practice. In this respect, (1) Cecelia Lynch's critical interpretivism (1999) allows for a reflexive exposition of the racist underpinnings of the discipline (2019); (2) Felix Ciuta's hermeneutical framework for security analysis $(2007 ; 2009)$ provides for an interpretive lens in the subfield dominated by positivist and poststructuralist sensibilities; (3) Anje Wiener's scholarship on norm contestation mo- 
bilises Wittgensteinian premises of meaning-in-use $(2009 ; 2014)$ to conceive of norms as outcomes of continuous interaction and communication, in contrast to the standard model of "norm cascade" (Finnemore, Sikkink, 1998); and (4) Lee Anne Fujii's methodological apparatus most distinctively translates interpretive premises into the practice of empirical research on violence and ethnic conflict (2010; 2015; 2018). Interpretive arguments that these authors advance problematise basic concepts in International Relations and show the analytical purchase of interpretive inquiry.

\section{The monist world of interpretivists}

\section{'The web of meaning'}

Interpretivists across social sciences often cite Geertz's famous statement about the human actor being "(...) an animal suspended in webs of significance he himself [sic!] has spun," the fact which requires an analysis "which is not an experimental science in search of law but an interpretive one in search of meaning" (Geertz, 1973, p. 5). Interpretivists study situated meanings and meaning-making practices of actors in a given setting rather than generalised meanings abstracted from particular contexts (Schwartz-Shea, Yanow, 2012). This is a vivid description of the monist understanding of social reality. Whereas positivists are philosophical dualists who situate themselves as separate from the world they observe, interpretivists reject the possibility of such separation (Jackson, 2011). They dismiss the dualistic picture of actors as knowing subjects who construct mirror-like representations of a mind-independent world (Ibid.). They therefore also deny the correspondence theory of truth, that is, the notion that we can establish an unequivocal correspondence between the truth or falsity of a statement and the real state of affairs (Lynch, 2014). This means that, in contrast to positivists, interpretivists do not in a direct sense 'test' theory but arrive at theoretical arguments via a recursive and iterative back-and-forth between theoretical frameworks and data generation. Accordingly, they see "the view from nowhere" or "the ambition of transcendence" (Nagel, 1989), a claim to objectivity which is a necessary condition for producing warranted positivist knowledge, as a social position that reflects embeddedness in a particular context. When pronounced from the position of power, for example from a dominant social standing, such claims to neutrality reflect and reproduce the extant power relations. For interpretivists, knowledge production results instead from intersubjective, meaning-focused processes that themselves interact with, and potentially shape, the studied world (Lynch, 2014). Such ontological position collapses the factvalue distinction. It is not, however, a call for relativism but a reflection of the in- 
terpretivist tradition wherein things, social facts, and events cannot be separated from the "value" attached to them by participants, observers, and evaluators (Ibid., p. 14). The claim to distance is nothing more but a stance and a cognitiveemotional orientation (Kondo, 1986, p. 75). This makes interpretive contextualisation of social phenomenon all the more important for interrogating conditions of knowledge production.

\section{Value-laden facts}

Social embeddedness and the value-laden character of the scientific process bring to bear porousness between theory and policy. Oren (1995) illustrates, for example, how the democratic peace thesis - that is, the claim that democracies do not wage war against other democracies, which is widely regarded as one of few laws in IR - is a historically specific and value-laden agenda. His study of the US-based democratic peace scholarship revealed the extent to which the latter was guided by a priori assumptions regarding the categorisation and accumulation of data, resulting in pre-determined conclusions where "democracy" stood for "Americalike" (Oren, 2003, p. 179). Europeanisation literature that focuses on norm diffusion and compliance with EU standards by the acceding countries is similarly an example of a scientific programme where the merger of fact and value is implicit but ontologically defining. Embracing the ideal of "the normative power Europe" (Manners, 2002), such literature assumes the EU's right and capacity to transform other societies towards a distinct normative model. It invests in tools of scientific inquiry to evaluate institutional convergence "as if" the model and the process of evaluation were apolitical. Rather than insisting that neutrality can be obtained, interpretivists approach knowledge production as any other social practice which is a result of intersubjective processes wherein fact and value are symbiotically related. Social science, in other words, is always perspectival and invested in the pursuit of moral or material goods (Schaffer, 2016, p. 2).

In order to tackle this conundrum, interpretivists interrogate social realities, including processes of knowledge production, by means of reflexive methodologies, defined by Jackson (2011, pp. 199-200) as "a dialectical interplay between social conditions and explicit attempts to delineate them (...) theorising one's own location to expose the ways in which knowledge is implicated in the social order", and "foregrounding unresolved tensions with situated knowledge". The monist understanding of social reality exposes the presumed gap between theory and policy as an illusion, or a 'useful fiction'. Interpretive policy fieldworkers in IR show instead the overlap and de facto co-authorship of knowledge claims, which poses serious and particular challenges to scholarly critique: How to deconstruct an ideological formation as contingent if the conditions of possibility 
of one's own knowledge claims are rooted in that very formation? (cf. Kurowska, Tallis, 2013). The famous example of Cohn's research among defence intellectuals (Cohn, 1987) where she recounts being caught in using their own securitising and gendered language despite her initial rejection of such mindset (2006) illustrates the complexity of that type of knowledge production. As researchers, we can no more transcend the context of the production of our knowledge claims than practitioners in other fields can transcend the social embeddedness of their practices. To bring in Gadamer's word of caution, "[trying] to escape from one's own concepts in interpretation is not only impossible but manifestly absurd" (Gadamer, 1998, p. 415). The logic of the hermeneutical circle brings this dilemma into sharp relief; it also sketches pathways towards approaching it as a generative rather than paralysing condition.

\section{Intersubjectivity and the hermeneutical circle}

The notion of intersubjectivity and the hermeneutical circle underpin the monist engagement with social reality. Neufeld (1993) usefully sharpens the concept of intersubjectivity in opposition to the positivist idea of 'subjective meanings' or 'consensus. The latter two presuppose individual consciousness while intersubjective meanings "could not be the property of a single person because they are rooted in social practice" (Taylor, 1971, p. 58). Socially embedded intersubjective meanings constitute instead 'the web of meaning,' that is, "the web of language, symbol, and institutions that constitutes signification" (Rabinow, Sullivan, 1987, p. 27). The task of interpretive inquiry is, therefore, to figure out the contextual logic which makes coherent "the actions of an agent and the meaning of the situation" (Taylor, 1977, p. 47). This does not denote that the actor's statements are to be taken at face value; they should rather be located within a broader web of narratives (Soss, 2006). The question to follow in research is then "What frameworks do participants use to make sense of their situation?" and "How individual comments are part of a whole, and how they are commentaries on one another?" (Ibid., p. 129). Our interlocutors' statements are the analytical entry point for making sense of the social world so the notions the actors have about their actions cannot be left exogenous to the descriptions and explanations of actions (Kratochwil, 2008). In other words, interpretive inquiry does not rely on exogenous models. But, crucially, neither is such inquiry about empathy which derives from methodological individualism and presupposes the possibility of pinning down discretely what the other thinks and feels. The properties of intersubjectivity in the monist world of interpretivists require instead turning to the hermeneutical circle for methodological guidance.

The methodology of the hermeneutical circle departs from a linear and step-by-step model of the scientific method and instead "[depicts] a circular, iterative 
sense making in which initial interpretation starts at whatever point is available or accessible, with whatever one's understanding is at that point in time" (Yanow, 2006, p. 16). As both the researcher and her interlocutors bring to bear prior experience and knowledge, the very possibility of making meaning, the hermeneutical circle is a space where Erlebnis (lived tradition) mediates Verstehen (understanding), and research questions, assumptions and theories derive from that context (Lynch, 2014, p. 17). There is 'testing' in the hermeneutical circle but it is not performed against an objective standard. Interpretive 'testing' involves investigating "the adequacy of a proffered 'reading' in terms of the concrete social practices in which it is embedded" and if, successful, it constitutes a refinement of particular interpretations in terms of other interpretations (Neufeld, 1993, p. 48). The criteria for assessment of interpretive work, what Schwartz-Shea and Yanow (2012) call "designing for trustworthiness," lay out benchmarks consistent with the conditions of knowledge production within the hermeneutical circle. Rather than of rigour and replicability demanded in the positivist paradigm, they speak of systematicity of inquiry and include reflexivity (see below) and "member-checking," that is, bringing the interpretations back to interlocutors, to probe adequacy of interpretation (Ibid., pp. 91-112).

Reasoning in intersubjective terms has changed IR inquiry. The contemporary world order and the organisations of communities in states relating to each other through diplomatic agents is an example of the 'web of meaning' in international politics (Cox, 1981). Notions of international system and international society, originally conceived in the English School of IR, indicate the constitutive role of the rules and norms, that is, intersubjective meanings. Interpretivists challenge the orthodox definition-based invocation of staple IR concepts by insisting that they need to be located in their context of use (for security see Wolfers, 1952; for norms see Wiener, 2009). When intersubjectively approached, norms, for example, are not objects or variables, but should be understood as elements of constitutive practices and relations which are produced through communicative activity (Laffey, Weldes, 1997). The balance of power, further, is usually parsed as a systemic effect. But any concrete security constellation can only be made sense of within a concrete and historically-specific web of meaning about national and international security. The question of whether military capabilities produce either safety or threat cannot be adjudicated "without understanding who possesses them, against whom they are targeted, and how the construction of those against whom they are targeted as 'enemies' has taken place" (Lynch, 2014, p. 15). 


\section{Indeterminacy of language}

Intersubjectivity implies the acknowledgment of both the importance of language and its indeterminacy. Language cannot represent reality or truth in a total sense because it is socially mediated and temporally and geographically conditioned (Lynch, 2014, p. 16). The apparent equivalence of language-in-use across interlocuters should not be seen as equivalence of meaning: a more thorough interpretive investigation will show that different meanings may be expressed through what the researcher initially sees as identical or interchangeable vocabulary (Soss, 2006). Still, the use of language and the meaning that social practices acquire in the process show intersubjectivity, language, and institutions as mutually constitutive (Taylor, 1971, p. 121): Intersubjective meanings, expressed in some form of language, and institutional practice shape each other. The type of language used shapes action and contains moral judgement, as is often exemplified in international law. As Lynch illustrates (2014, pp. 15-16), the use of the term "genocide" instead of "group or ethnic killing" by the UN Security Council to describe a conflict should set in motion the provisions of UN Charter Chapter VII to stop it, while an application of a different term, such as "civil war," presents a wider decision-making latitude. Interpretivists also adapted Wittgenstein's notion of 'language games' to study the use of language in international politics (Hollis, Smith, 1991, pp. 171-196; Fierke, 1998; 2001). Learning to play a game (do politics, produce knowledge) is like learning a language: one needs to absorb the intersubjective rules and their meaning in order to make sense of one's own position and interactions with others. Signalling among adversaries as understood in deterrence, for example, cannot take place without intersubjective understanding (Kratochwil, 1989).

\section{Abduction, explication, reflexivity}

As Lynch further develops, indeterminacy of meaning and contextualization result in "expanded notions of causality, beyond monocausality and ahistorical covering law explanations, to include multi-causality, mutual constitution, and contingency" (Lynch, 2014, p. 22). She refers to Hesse's argument about social events being underdetermined (1978), the abductive logic of inquiry that interpretivists espouse, and the notion of 'explication' inspired by Richard Rorty to describe what these expanded notions of causality mean in interpretivist inquiry. In traditional IR, events are often seen as overdetermined, that is, the task of a non-interpretive scholar is to figure out the real cause out of a seeming abundance of factors that might have prompted a particular course of action (Lynch, 2014, p. 13). Hesse (1978) shows, however, that phenomena are under- 
determined by the available evidence, which means that no evidence can prove beyond doubt that a particular event derived from a specific cause. This is why, Lynch continues, we rely on interpretation to assign causality between political phenomena (Lynch, 2014, p. 14).

Given that evidence cannot perfectly support unique causes of social phenomena, the logic of inquiry that best suits interpretive practices of knowledge production is abduction. In contrast to deductive theories testing 'trial and error', or the inductive derivation of theoretical propositions from empirical observations, abduction relies on a "processual merger of creativity, experimentation, testing and adaptation" (Hellmann, 2009, p. 641). As a form of hunting for clues to make a diagnosis under conditions of uncertainty, abduction is by default inconclusive: It is a mode of inference that looks for congruent categories without assuming their completeness or primacy (Onuf, 2013, pp. 98-107). 'Explication, in this context of indeterminacy, is not an empirical discovery that explains in terms of ascribing a causal status to specific variables. In Rorty's pragmatic philosophy of language, explication is a process of re-description that introduces revisions to make something explicit from the position of 'where one is' (Gascoigne, 2008). Explication is therefore a contingent and context-specific outcome, open to subsequent revisions, in line with the principle of the hermeneutical circle of meanings being always incomplete. The claim to the researcher's objectivity must be abandoned within such parameters. But interpretivists have their own counterpoint to objectivity congruent with their monist stance, that is, reflexivity, which strengthens both ethical integrity and theoretical robustness of their arguments (Schwartz-Shea, Yanow, 2012, p. 100). Reflexivity can be defined as "a keen awareness of, and theorizing about, the role of the self in all phases of the research process" (Schwartz-Shea, 2006, p. 102). It shows the role of the researcher as embedded in the social context of knowledge production and her role in the construction of the research problem, yet it is not akin to acquiring the truth through introspection. The standard components of reflexive accountability include interrogating the researcher's own characteristics, her theoretical and political commitments deriving from the scholarly communities she inhabits, her social background, and the socio-historical context. These will never, however, be fully transparent but rather constitute continuous probes and puzzles for the researcher concerned with imposing meaning (Kurowska, 2019c). The results of research encounters are not seen as final outcomes but, again, as part of the continuous process of explication. 


\section{Interpretive inquiry - examples}

Cecelia Lynch has been at the forefront of interpretive IR for the last couple of decades, contributing to theory-informed empirical research which puts interpretive philosophical ideals in practice in daily research struggles. In a pioneering book, Beyond Appeasement: Interpreting Interwar Peace Movements in World Politics, Lynch describes her version of interpretivism as "a critical stance toward entrenched narratives in order to reconstruct interpretations that address the complexity of social movement agency" (1999, p. 2). This purpose, she continues, must come with reflexive scrutiny of one's own interpretive frames: "Not only should we be wary of the narratives constructed by participants (...), but we should also be critical of the narratives we construct to analyse them" (Ibid., p. 217). This "reflexive methodology" is exemplified in her scholarship in, on the one hand, an interrogation of the ethical and generative dimension of the researcher's involvement in the research relationship (2008), and, on the other, in socio-historical contextualisation, as in her recent exposition of racist legacies in IR scholarship (2019). The former illustrates the striving for constructivist reflexivity by confronting the risk of imposing meaning when the researcher's ideological frame, which, as hermeneutics teaches us, cannot be abandoned (cf. Gadamer, 1989), is different from that of her interlocutors who may also be in structurally disadvantaged positions. The latter points to structures of intersubjective meaning that continue to affect knowledge production in IR: In this case, the racialised international political practices, which marked the beginning of the discipline, and persist to shape "theoretical assumptions, deferrals, and absences in ways that continued to resonate throughout the century" (Lynch, 2019, p. 267).

Felix Ciuta has contributed to interpretive theory and research in security studies. He examines, for example, the false dichotomy between strategy and identity, which traditionally are opposing variables in research on European security (Ciuta, 2007). The dichotomy finds its expression in the question of whether the EU security and foreign policy actors act on strategically determined interests or on EU identity, that is, a set of internalised liberal values. He sees this as a misguided question in the first place: The question operates with discrete values and actors, neglecting the role of context and the process of mutual constitution of actors and their practices which follows from the principle of intersubjectivity. Further, no decisive evidence can be brought forward to adjudicate this question, which links back to the idea of underdetermination. Ciuta resorts instead to 'narrative' as a hermeneutical device which allows for "(...) useful insights in the constitution, transformation and sedimentation of categories of meaning" (Ciuta, 2007, p. 192). He develops the concept of 'narrative shuttle' to capture the enmeshment of strategy and identity in security policy and the co-existence 
of polysemy of meaning out of which actors continuously produce narrative 'coherence.' His hermeneutical framework for security analysis (Ciuta, 2009)refines an intersubjective understanding of security as both a product of and constitutive of context. He does so by probing the consistency of the constructivist precept of securitisation theory that "security is what actors make of it" (Buzan, Wæver, 2003, p. 48), which implies that "the analysis of security would no longer proceed by applying a conceptual framework to an empirical context. Instead, the concept of security, and by extension security theory in general, would become entirely contextual" (Ciuta, 2009, p. 302). Yet, despite its claim to innovation, securitisation lays out a rather traditional framework to be followed. Such inconsistency is not only a specific weakness of securitisation theory. It illustrates well the common discrepancy between interpretive declarations and non-interpretive theorisation which falls back on methodological orthodoxies. A thoroughly contextual analysis that interpretivists envisage is laborious and contingent, as it rejects analysis based on a priori models. Contextual analysis is demanding for the investment and commitment it requires but also because it takes away the sense of control, and of the epistemological superiority, held by the researcher.

Antje Wiener from early on in her research illuminated the dialectical relationship between context, language, and institutional transformation that, for example, made both NATO and EU enlargement possible (Fierke, Wiener, 1999). Her scholarship on norms in international politics directly confronts the orthodox model of normative change described as "norm cycle/cascade" (Finnemore, Sikkink, 1998). In that model, strategic action by norm entrepreneurs may lead to "a tipping point", which is the moment when enough actors in a group characterise the norm as central to their identity. After this moment, a norm becomes part of relevant actors' identity and therefore triggers the normative pull to comply. The major issue that interpretivists have with such framing is a view on norms as discrete and relatively stable objects rather than intersubjective processes. Norms are either taken over or rejected, yet this fails to capture the reciprocal exchange between actors that negotiate the validity, meaning and application of norms (Kurowska, 2019a, pp. 6-7). In other words, the model presents a unidirectional causal story "from socialiser to socialisee" (Epstein, 2012, p. 140). Wiener (2015) offers the principle of contestedness ${ }^{1}$ to reverse this perspective on norm transfer as a linear trajectory from the centre towards the periphery which

Wiener defines this principle more broadly as: "[reflecting] the global agreement that, in principle, the norms, rules and principles of governance are contested and that they therefore require regular contestation in order to work. For the legitimacy gap between fundamental norms and standardised procedures to be filled, therefore, access to regular contestation (as opposed to ad-hoc contestation) needs to be facilitated, in principle, for all involved stakeholders" (Wiener, 2014, p. 3). 
is expected to internalise these norms. She shows how outsiders may be attracted to some parts of the EU's acquis and choose to copy bits and pieces only. Contestedness and mutual constitution change the mode of analysis, from the focus on compliance, informed by the positivist imaginary of discrete and hierarchical entities, to the focus on intersubjective normative relations. In such constellations, the meaning of norms is in their use, a principle that follows from the Wittgensteinian philosophy of language (Wiener, 2009). Rather than investigate to what extent actors comply with or follow the norm, as has been the standard of Europeanisation literature, for example, an interpretive inquiry examines the mutual constitutiveness of the norms and actions of agents, that is, what the norm means to the actors in practical terms (cf. Kurowska, 2014).

Lee Anne Fujii has made important substantive and methodological contributions to interpretive IR, starting with her research on probing localised interpretations of the Rwandan genocide, which brought contextual nuance to the preponderance of ethnicity-based explanation (Fujii, 2011). With her research question of "How do ordinary people come to commit genocide against their neighbours?," she developed research strategies that considered the local context and local meanings of violence. Specifically, she reconstructed the local practices of recruitment to violence which relied on cross-ethnic local ties. Fujii's scholarship added, more broadly, to methodological advancement and research practice of interpretive IR fieldworkers. She introduced, for example, the notion of "metadata", that is, spoken and unspoken thoughts and feelings which participants do not always articulate in interviews, but which emerge in other ways (Fujii, 2010). She mentioned at least five types of such data - rumours, inventions, denials, evasions, and silences - as integral to the processes of data generation and analysis. Meta-data are crucial to interpretive inquiry as they indicate what intersubjective rules operate within a community, 'the 'web of meaning' which the researcher seeks to piece together by participation and conversation with community members. Bliesemann and Kühn (2015) apply the notion of metadata in their research on international interveners in Afghanistan and Kosovo to make sense of episodes that happened to 'a colleague of a colleague.' This interpretive methodological strategy leads to explicating a deeper level of meaningmaking in peacebuilders' own roles, their interactions with 'the locals', and, by extension, the failures of peacebuilding. The themes they encountered of, among others, 'the intervened' as barbarians and 'the interveners' as plagued by western and northern hubris, resonate with old colonial tropes and provide a more nuanced insight into the practices of contemporary peacebuilding.

Fujii (2018) also developed the relational approach to interviewing for interpretive IR fieldwork. It translates the premises of the hermeneutical circle into interviewing as a two-way dialogue rather than surveying or interrogating interlocutors. She depicts such conversation as happening in concrete socio-historical 
contexts, political settings, and as affected by never fully transparent modalities of the situational research relationship, although it is through these interactions that data are generated and knowledge claims constructed. She, consequently, speaks of the limitations to such relationships and prefers to call them "working relationships" rather than rapport. The presumption of familiarity, similarly to that of equivalence of meaning as mentioned above, is suspicious for interpretivists. It distorts sense-making and often leads to the researcher imposing their frame, or meaning-making practices, on the interlocutor (Kurowska, 2019b).

\section{Conclusion}

We interpret all the time: as IR researchers, subjects of international politics, and lay participants in daily lives. There is, however, an element of 'Cartesian anxiety' in embracing this condition of knowledge production across all levels. The anxiety reflects fear of anti-foundationalism which tends to be mistakenly identified as relativism, and uneasiness with the challenge to the presumed certainty of the scientific method. Such anxiety is understandable. Yet it operates on a distinct misunderstanding about the extent of systematicity and contextual nuance brought by interpretive inquiry which studies the polysemy of social reality rather than replicating models thereof. With several decades of time lag, as often happens, IR has been incorporating interpretive theorising and engaging in interpretive empirical research because, quite simply, old frameworks are no longer that useful for making sense of international politics in the contemporary era. This development will only intensify, as will also, however, the ideological polarisation across scholarly paradigms, confronting us with the continuous normative saturation of scholarly endeavour.

\section{References}

Bevir, M., Hall, I. (2020). "The English School and the Classical Approach: Between Modernism and Interpretivism". Journal of International Political Theory, first view.

Bevir, M., Phillips, R. (eds.). (2019). Decentring European Governance. London-New York: Routledge.

Bevir, M., Rhodes, R.A.W. (eds.). (2016). Routledge Handbook of Interpretive Political Science. London-New York: Routledge.

Bliesemann de Guevara, B. (ed.). (2016). Myth and Narrative in International Politics: Interpretive Approaches to the Study of International Relations. London: Palgrave Macmillan.

Bliesemann de Guevara, B., Kühn, F.P. (2015). "On Afghan Footbaths and Sacred Cows in Kosovo: Urban Legends of Intervention". Peacebuilding, 3(1), pp. 17-35. 
Burawoy, M. (1998). “The Extended Case Method”. Sociological Theory, 16(1), pp. 4-33. Buzan, B., Wæver, O. (2003). Regions and Powers: The Structure of International Security. Cambridge: Cambridge University Press.

Ciuta, F. (2007). "Narratives of Security: Strategy and Identity in the European Context". In: R. Mole (ed.). Discursive Constructions of Identity in European Politics. London: Palgrave Macmillan, pp. 190-207.

Ciuta, F. (2009). "Security and the Problem of Context: A Hermeneutical Critique of Securitisation Theory”. Review of International Studies, 35(2), pp. 301-326.

Cohn, C. (2006). "Motives and Methods: Using Multi-sited Ethnography to Study US National Security Discourses”. In: B. Ackerly, M. Stern, J. True (eds.). Feminist Methodologies for International Relations. New York: Cambridge University Press, pp. 91-107.

Cox, R. (1981). "Social Forces, States and World Orders: Beyond International Relations Theory”. Millennium, 10(2), pp. 126-155.

Epstein, Ch. (2012). “Stop Telling Us How to Behave: Socialization or Infantilization?”. International Studies Perspectives, 13, pp. 135-145.

Fierke, K.M. (1998). Changing Games, Changing Strategies: Critical Investigations in Security. Manchester, UK: Manchester University Press.

Fierke, K.M. (2001). “Critical Methodology and Constructivism”. In: K.M. Fierke, K.E. Jørgensen (eds.). Constructing International Relations: The Next Generation. Armonk, NY: M.E. Sharpe, pp. 115-135.

Fierke, K.M., Wiener, A. (1999). "Constructing Institutional Interests: EU and NATO Enlargement”. Journal of European Public Policy, 6(5), pp. 721-742.

Finnemore, M., Sikkink, K. (1998). "International Norm Dynamics and Political Change". International Organization, 52, pp. 887-917.

Fujii, L.A. (2010). "Shades of Truth and Lies: Interpreting Testimonies of War and Violence". Journal of Peace Research, 47(2), pp. 231-241.

Fujii, L.A. (2011). Killing Neighbors: Webs of Violence in Rwanda. Ithaca: Cornell University Press.

Fujii, L.A. (2018). Interviewing in Social Science Research: A Relational Approach. New York, NY: Routledge.

Gadamer, H.-G. (1989). Truth and Method. London: Sheed \& Ward.

Gascoigne, N. (2008). Richard Rorty: Liberalism, Irony, and the End of Philosophy. Cambridge: Polity.

Geertz, C. (1973). The Interpretation of Cultures. New York: Basic Books.

Hellmann, G. (2009). "Pragmatism and International Relations”. International Studies Review, 11(3), pp. 638-641.

Hesse, M. (1978). “Theory and Value in the Social Sciences”. In: C. Hookway, P. Pettit (eds.). Action and Interpretation: Studies in the Philosophy of the Social Sciences. Cambridge: Cambridge University Press, pp. 1-16.

Hollis, M., Smith, S. (1990). Explaining and Understanding International Relations. Oxford: Oxford University Press.

Jackson, P.T. (2011). The Conduct of Inquiry in International Relations: Philosophy of Science and Its Implications for the Study of World Politics. New York-London: Routledge. 
Kondo, D.K. (1986). "Dissolution and Reconstitution of Self: Implications for Anthropological Epistemology”. Cultural Anthropology, 1(1), pp. 74-88.

Kratochwil, F. (1989). Rules, Norms and Decisions: On the Conditions of Practical and Legal Reasoning in International Relations and Domestic Affairs. Cambridge: Cambridge University Press.

Kratochwil, F. (2008). “Constructivism: What It Is (Not) and How It Matters”. In: D. della Porta, M. Keating (eds.). Approaches and Methodologies in the Social Sciences: A Pluralist Perspective. Cambridge: Cambridge University Press, pp. 80-98.

Kurowska, X. (2014). "Practicality by Judgement: Transnational Interpreters of Local Ownership in the Polish-Ukrainian Border Reform Encounter". Journal of International Relations and Development, 17(4), pp. 545-565.

Kurowska, X. (2018). "EU Foreign Policy." In: H. Heinelt, S. Münch (eds.). Handbook of European Policies: Interpretive Approaches to the EU. Cheltenham: Edward Elgar Publishing, pp. 273-287.

Kurowska, X. (2019a). The Politics of Cyber Norms: Beyond Norm Construction towards Strategic Narrative Contestation. Paris: EU Institute for Security Studies.

Kurowska, X. (2019b). "When Home Is Part of the Field: Experiencing Uncanniness of Home in Field Conversations”. In: B. Steele, H. Gould, O. Kessler (eds.). Tactical Constructivism: Expressing Method in International Relations. London-New York: Routledge, pp. 105-116.

Kurowska, X. (2019c). "When One Door Closes, Another One Opens? The Ways and Byways of Denied Access, or a Central European Liberal in Fieldwork Failure”. Journal of Narrative Politics, 5(2), pp. 71-85.

Kurowska, X., Bliesseman de Guevara, B. (2020). "Interpretive Approaches in Political Science and International Relations”. In: L. Curini, R. Franzese (eds.). The SAGE Handbook of Research Methods in Political Science \& International Relations. London: Sage, pp. 1221-1240.

Kurowska, X., Tallis, B.C. (2013). "Chiasmatic Crossings: A Reflexive Revisit of a Research Encounter in European Security”. Security Dialogue, 44(1), pp. 73-89.

Laffey, M., Weldes, J. (1997). "Beyond Belief: Ideas and Symbolic Technologies in the Study of International Relations”. European Journal of International Relations, 3(2), pp. 193-237.

Lynch, C. (1999). Beyond Appeasement: Interpreting Interwar Peace Movements in World Politics. Ithaca: Cornell University Press.

Lynch, C. (2008). "Reflexivity in Research on Civil Society: Constructivist Perspectives". International Studies Review, 10(4), pp. 708-721.

Lynch, C. (2014). Interpreting International Politics. New York: Routledge.

Lynch, C. (2019). “The Moral Aporia of Race in International Relations”. International Relations, 33(2), pp. 267-285.

Manners, I. (2002). “Normative Power Europe: A Contradiction in Terms?”. Journal of Common Market Studies, 40(2), pp. 235-258.

Nagel, T. (1989). The View from Nowhere. Oxford: Oxford University Press.

Neufeld, M. (1993). “Interpretation and the 'Science' of International Relations”. Review of International Studies, 19, pp. 39-61.

Onuf, N. (2013). World of Our Making: Rules and Rule in Social Theory and International Relations. $2^{\text {nd }}$ ed. London-New York: Routledge. 
Oren, I. (1995). “The Subjectivity of the 'Democratic' Peace: Changing U.S. Perceptions of Imperial Germany”. International Security, 20(2), pp. 147-184.

Oren, I. (2003). Our Enemies \& US: America's Rivalries and the Making of Political Science. Ithaca, NY: Cornell University Press.

Rabinow, P., Sullivan, W.M. (eds.) (1987). Interpretive Social Science: A Second Look. Berkeley: California University Press.

Schaffer, F.C. (2016). Elucidating Social Science Concepts: An Interpretivist Guide. New York: Routledge.

Schwartz-Shea, P. (2006). “Judging Quality: Evaluative Criteria and Epistemic Communities”. In: D. Yanow, P. Schwartz-Shea (eds.). Interpretation and Method: Empirical Research Methods and the Interpretive Turn. Armonk, NY-London: M.E. Sharpe, pp. 89-114.

Schwartz-Shea, P., Yanow, D. (2012). Interpretive Research Design: Concepts and Processes. New York-London: Routledge.

Soss, J. (2006). “Talking Our Way to Meaningful Explanations”. In: D. Yanow, P. SchwartzShea (eds.). Interpretation and Method: Empirical Research Methods and the Interpretive Turn. Armonk, NY-London: M.E. Sharpe, pp. 127-150.

Taylor, Ch. (1971). "Interpretation and the Sciences of Man". Review of Metaphysics, 25(1), pp. 3-51.

Wedeen, L. (2010). "Reflections on Ethnographic Work in Political Science". Annual Review of Political Science, 13, pp. 255-272.

Wiener, A. (2009). "Enacting Meaning-in-Use: Qualitative Research on Norms and International Relations”. Review of International Studies, 35(1), pp. 175-193.

Wiener, A. (2014). Theory of Contestation. Heidelberg: Springer.

Wiener, A. (2015). "In the Eye of the Beholder: A Sociology of Knowledge Perspective on Norm Transfer”. Journal of European Integration, 37(2), pp. 11-228.

Wolfers, A. (1952). “National Security' as an Ambiguous Symbol”. Political Science Quarterly, 67(4), pp. 481-502.

Yanow, D. (2006). "Thinking Interpretively Philosophical Presuppositions and the Human Sciences”. In: D. Yanow, P. Schwartz-Shea (eds.). Interpretation and Method: Empirical Research Methods and the Interpretive Turn. Armonk, NY-London: M.E. Sharpe, pp. 5-26.

Yanow, D., Schwartz-Shea, P. (eds.). (2006). Interpretation and Method: Empirical Research Methods and the Interpretive Turn. Armonk, NY-London: M.E. Sharp. 